\title{
Hak Biokultural Masyarakat \\ Dalam Kebijakan Konservasi Sumber Daya Hayati
}

Rika Fajrini ${ }^{1}$

\begin{abstract}
Abstrak
Tulisan ini akan membahas mengenai perkembangan hak biokultural dalam hukum internasional dan bagaimana kebijakan dan hukum konservasi Indonesia mengakomodasi hak biokultural masyarakat. Dari penelitian ini ditemukan bahwa hak biokultural masyarakat adat dan masyarakat lokal sudah mendapatkan pengakuan di beberapa instrumen hukum lingkungan internasional. Peraturan konservasi Indonesia pun telah mengakui hak biokultural masyarakat yang biasa diasosiasikan dengan kearifan lokal dan hak ulayat. Namun sejauh mana pengakuan ini diwujudkan dalam tindakan dan mekanisme konkrit di lapangan masih memerlukan perbaikan. Kebijakan konservasi saat ini pun lebih menempatkan negara sebagai aktor utama konservasi, hal ini membuat konservasi yang berbasis pengampuan masyarakat menjadi terabaikan.
\end{abstract}

Kata Kunci: hak biokultural, konservasi, masyarakat lokal

\begin{abstract}
This paper will discuss about the development of biocultural right in international environmental law and how Indonesia policy and law on conservation accomodates communities biocultural right. This research found that biocultural right have been recognized in several international law instrument and jurisprudence. Meanwhile, Indonesia law and policy on conservation also have acknowledge biocultural right which is usually associated with the term of local wisdom and customary right, However, improvement is still needed in term of translating this regulation into concrete action and system of conservation management. The current policy conservation centered around state as the main actor, this situation make the conservation based on community's stewardship is neglected.
\end{abstract}

Keywords: biocultural rights, conservation, local community

1 Mahasiswa Pasca Sarjana Ilmu Lingkungan di Universitas Kyoto, Jepang. Mendapatkan gelar Sarjana Hukum dari Universitas Indonesia. 


\section{Pendahuluan}

Keanekaragaman budaya dan keanekaragaman hayati sekilas seperti dua hal penting yang sama-sama harus dilestarikan namun tidak begitu berkaitan. Sehingga, pembahasan mengenai konservasi keanekaragaman hayati terkadang terjebak dalam diskursus yang sangat teknokrat dan ilmiah, luput membahas mengenai unsur kebudayaan yang terkait dengannya. Padahal, pada prakteknya, dua hal ini memiliki keterkaitan yang saling mempengaruhi. ${ }^{2}$ Budaya di suatu wilayah lahir dari interaksi panjang antara masyarakat lokal dengan lingkungan sekitarnya. Budaya tersebut merupakan bentuk adaptasi dan respon masyarakat lokal terhadap kondisi alam, seperti teknik pembuatan rumah Suku Bajau yang hidup di perairan. Budaya juga dapat mempengaruhi alam sekitar, seperti budaya makan nasi mempengaruhi budidaya beragam varietas padi di Asia, sementara di kawasan timur Indonesia, makanan pokok lebih pada umbi-umbian dan kacangkacangan, hal ini juga mempengaruhi keanekaragaman varietas tanaman ini di wilayah tersebut. ${ }^{3}$

Berbagai studi antropologi mengindikasikan daerah-daerah dengan tingkat keanekaragaman hayati tinggi biasanya merupakan daerah yang didiami oleh masyarakat adat tradisional terutama di wilayah Amerika Latin, Afrika dan Asia Tenggara. ${ }^{4}$ Bahkan hutan Amazon - wilayah yang terkenal dengan kemurnian alamnya - merupakan rumah bagi ratusan kelompok masyarakat adat. Mereka telah menjadi pengampu bagi alam sekitarnya dari generasi ke generasi. Tugas pengampuan ini memberikan hak dan kewajiban tersendiri bagi mereka terhadap

2 Gagasan mengenai hubungan tak terpisahkan antara keanekagaraman budaya dan keanekaragaman hayati pertama kali dikemukakan dalam Deklarasi Belém oleh Komunitas Internasional Etnobiologi pada tahun 1988 (http://ise.arts.ubc.ca/declareBelem.html). Penelitian etnobiologi dan etnoekologi selama bertahun-tahun telah mengumpulkan buktibukti ilmiah mengenai pengetahuan masyarakat adat dan masyarakat lokal mengenai tumbuhan, hewan, habitat serta fungsi ekologis dan relasinya, juga penggunaan sumber daya alam secara berkelanjutan. Hal ini menyanggah pandangan mengenai perlindungan terhadap alam yang murni dengan cara memagarinya dari aktivitas manusia. Lihat Luisa Maffi, Biocultural Diversity and Sustainability, The Sage Handbook of Environment and society, (Sage Publication Ltd,2008), hlm. 268-269

3 Suku Dani di Palimo, Lembah Baliem mengembangkan 74 varietas ubi, sementara komunitas masyarakat adat yang hidup di ekosistem rawa bagian selatan Pulau Kimaam Kabupaten Merauke mengembangkan 144 varietas ubi. Lihat Abdon Nababan, Pengelolaan Sumber daya Alam Berbasis Masyarakat Adat, Tantangan Dan Peluang Kearifan Tradisional : Awal bagi Pengabdian Pada Keberlajutan Kehidupan, makalah disajikan dalam "Pelatihan Pengelolaan Lingkungan Hidup Daerah" Pusat Penelitian Lingkungan Hidup, IPB, 5 Juli 2002,

4 Jules Pretty dkk, The Intersections of Biological Diversity and Cultural Diversity : Towards Integration Jules dalam Conservation and Society Journal, diunduh dari http://www. conservationandsciety.org pada tanggal 29 Oktober 2015. 
alam sekitar. Komunitas yang secara historis telah berinteraksi dengan lingkungan dan merupakan pihak yang paling terdampak langsung ini merupakan stakeholder penting dalam pembuatan keputusan terkait konservasi. Sudah seharusnya konservasi keanekaragaman hayati juga mempertimbangan keanekaragaman budaya sekitar. Kebijakan konservasi yang justru memutus hubungan kultural masyarakat dengan alamnya akan menerima resistensi tinggi dan berdampak pada pencapaian tujuan konservasi itu sendiri. Penghargaan terhadap hubungan kultural ini melahirkan hak biokultural masyarakat sebagai pengampu lingkungannya. Artikel ini akan membahas lebih lanjut mengenai perkembangan konsep hak biokultural serta sejauh mana hak biokultural ini diakomodasi dalam hukum dan kebijakan konservasi keanekaragaman hayati di Indonesia.

\section{Hak Biokultural Masyarakat Lokal Sebagai Pengampu Ekosistem}

\subsection{Apa itu Hak Biokultural?}

Secara singkat hak biokultural dapat diartikan sebagai hak yang berasal dari hubungan antara komunitas dengan lingkungannya. Hak biokultural ini diperlukan agar komunitas dapat menjalankan perannya sebagai pengampu ekosistem dan sumber daya alam. Peran pengampuan terintegrasi dalam cara hidup komunitas dimana identitas, budaya, spiritualitas, sistem pengelolaan dan penghidupan tradisional tidak lepas dari lingkungan ekosistem mereka. Hubungan komunitas dengan alamnya ini lebih pada tugas pengampuan (custodian/stewardship) dibanding wujud kepemilikan atas objek. Hak biokultural berbeda dengan hak properti lain yang memandang alam sebagai objek ekonomi yang dapat dijadikan komoditas, dipindahtangankan dan divaluasi dengan uang. ${ }^{5}$

Lingkungan yang mereka konservasi bukan lingkungan dalam makna akademis dan teknokratis, tapi lingkungan yang secara integral adalah bagian dari kehidupan mereka, alam bukanlah sesuatu 'diluar sana' yang harus dilindungi dengan berbagai aturan dan larangan, tapi merupakan identitas dan eksistensi dari masyarakat itu sendiri.

Beberapa penulis seperti Chen dan Gillmore mengasosiasikan hak biokultural selalu dengan hak masyarakat adat. Mereka mendefinisikan hak biokultural

5 Kabir Sanjay Bavikatte, Environmental Law as Political Ecology: The Roots of Biocultural Rights, diunduh dari http://dlc.dlib.indiana.edu/dlc/bitstream/handle/10535/7275/1220. pdf? sequence=1 pada tanggal 29 Oktober 2015. 
sebagai seperangkat hak adat yang mencakup baik hak atas wilayah ekosistem beserta sumber daya alam dan sumber daya budaya mereka (budaya, spiritualitas, manifestasi agama, pengetahuan dan teknologi tradisional) dengan kesadaran penuh bahwa kedua hal ini sangat terkait dan tidak terpisahkan. ${ }^{6}$ Namun Penulis sepakat dengan pendapat Bavikatte (2015) bahwa meskipun hak biokultural berkembang dalam gerakan hak masyarakat adat, tetapi klaim atas hak biokultural hendaklah tidak dibatasi bagi masyarakat adat saja. Masyarakat setempat dan komunitas lokal yang memiliki keterikatan dengan alam dan sumber daya hayatinya juga dapat dikatakan memiliki hak ini. Membatasi hak biokultural sebagai hak kolektif dari masyarakat adat saja akan menegasikan keberadaan kearifan lokal dalam komunitas yang belum tentu memenuhi kriteria masyarakat adat, ditambah lagi belum ada kesepakatan umum mengenai apa saja kriteria masyarakat adat tersebut. Seperti contoh masyarakat pendatang Bugis dan Makassar di sekitar Taman Nasional Kutai akan kesulitan mengklaim hak biokulturalnya jika harus membuktikan bahwa mereka adalah masyarakat adat asli di daerah tersebut. ${ }^{7}$ Hak petani (farmer rights) ${ }^{8}$ dan hak penggembala (pastoralist rights) ${ }^{9}$ juga bisa dikategorikan sebagai hak biokultural. Di Jepang, hak biokultural ini dikembangkan dalam bentuk manajemen satoyama dan satoumi yang mengedepankan simbiosis mutualisme antara manusia dengan alam sekitarnya. ${ }^{10}$

6 Chen, C. , Gilmore, M, Biocultural Rights: A New Paradigm for Protecting Natural and Cultural Resources of Indigenous Communities dalam The International Indigenous Policy Journal Vol 6 Issue 3, (Scholarship Western:2015), hlm. 8-10. Artikel dapat diunduh di http://ir.lib.uwo.ca/ cgi/viewcontent.cgi? article $=1205 \&$ context $=$ iipj

7 Gelombang kedatangan orang Bugis ke Sangkima (wilayah yang masuk dalam kawasan Taman Nasional Kutai) bermula dari hadirnya Datuk Solong bersama dua anaknya Dato La Talana dan Dato La Dolomong pada tahun 1922. Lihat Semiarto Aji Purwanto, Taman Nasional, Hak-hak Masyarakat Setempat dan Pembangunan Regional dalam Jurnal Antropologi Indonesia Vol. 29, No.3, 2005, hlm. 281-283

8 Hak petani (farmer rights) disini adalah hak yang diakui dalam International Treaty of Plant Genetic Resource for Food and Agriculture (ITPGRFA) dimana hak ini lahir dari rekognisi kontribusi mereka terhadap konservasi sumber daya genetik tanaman pangan. Hak petani ini dapat mencakup hak untuk menyimpan, menggunakan, saling menukar dan menjual bibit yang dikembangkannya, perlindungan atas pengetahuan tradisionalnya, partisipasi dalam pembuatan keputusan serta mendapat pembagian keuntungan yang adil atas pemanfaatan bibit yang dikembangkannya. Lihat Farmers' Rights in the International Treaty on Plant Genetic Resources for Food and Agriculture artikel dapat diunduh di http://www.farmersrights.org/ about/fr in itpgrfa.html

9 Hak Pastoralist mungkin tidak begitu terkenal di Indonesia sebagai daerah hutan hujan tropis. Pastoralist adalah komunitas yang hidup dengan menggembalakan ternak-ternak, biasanya komunitas ini terdapat di daerah-daerah kering yang sulit ditumbuhi tanaman seperti Afrika. Pastoralist sebagian besar hidup nomaden, mereka memiliki pemahaman unik tentang ekosistem sekelilingnya yang digunakan dalam managemen ternak dan lahan merumput bagi ternak-ternaknya.

10 Satoyama adalah lanskap socio-ekologis dari sebuah ekosistem darat, sato secara harfiah berarti "manusia" dan yama secara harfiah berarti hutan. Sementara Satoumi adalah lanskap socio- 
Di Indonesia sendiri, hak biokultural memiliki kesamaan dengan hak ulayat, terutama dalam hal keterikatan masyarakat pada alam sekitarnya, tidak hanya sebagai sumber daya ekonomi tapi juga media pengaplikasian budaya dan spiritualitas. Perbedaan antara hak biokultural dengan hak ulayat dapat kita lihat dari klaim atas hak ulayat, yang tidak hanya berdasarkan hubungan dengan alam (teritorial) tapi juga dapat berdasarkan hubungan darah (genealogis), selain itu hak ulayat hanya dimiliki oleh masyarakat adat yang biasanya memiliki hukum adat terkait pengelolaan wilayah adat serta sumber daya alamnya. Perundang-undangan terkait lingkungan biasanya telah menyebutkan penghormatan terhadap kearifan lokal sebagai salah satu asasnya. Hal ini dapat menjadi indikator bahwa hak biokultural telah diakui secara normatif, meskipun masih tidak jelas bagaimana asas ini diejawantahkan dalam praktek sehari-hari serta sejauh mana hak biokultural ini diakomodasi. Pengakuan ini lebih banyak diarahkan pada pengakuan hak ulayat masyarakat adat, advokasi hak-hak biokultural komunitas atau masyarakat lokal setempat belum banyak terdengar di Indonesia, hal ini juga disebabkan karena masyarakat lokal yang memiliki keterikatan kuat dengan alamnya biasanya diidentifikasi sebagai masyarakat adat.

Hak biokultural merupakan kontra argumen dari "tragedy of the common" Hardin yang menyatakan bahwa kepemilikan komunal sumber daya alam bersama akan membawa sumber daya alam tersebut pada kehancuran dan cara terbaik untuk melindungi alam adalah dengan privatisasi atau kontrol negara sehingga akses terhadap sumber daya dapat dibatasi. ${ }^{11}$ Argumen ini telah dibantah oleh ekonomis seperti Elinor Ostrom yang menjelaskan bagaimana sekumpulan orang yang saling bergantung satu sama lain dapat mengatur diri mereka sendiri guna mendapat keuntungan bersama yang berkelanjutan ditengah ancaman free-rider atau anggota kelompok yang oportunistik. ${ }^{12}$ Ostrom menyatakan teori tragedy of the common terlalu megeneralisasikan semua kelompok, seolah dalam kelompok tidak

ecologis dari sebuah ekosistem laut, sato secara harfiah berarti "manusia" dan umi secara harfiah berarti manusia.

11 Tragedy of The Common menjelaskan bahwa ketiadaan hak milik yang jelas atas sumber daya milik bersama akan memicu eksploitasi berlebihan terhadap sumber daya tersebut, karena pengguna tidak dibebani biaya apapun untuk memanfaatkannya. Garret Hardin mengilustrasikan teori tragedy of the common ini dengan kisah padang rumput yang rusak karena eksploitasi berlebihan karena tidak ada biaya apapun yang harus dikeluarkan penggembala untuk merumput di padang tersebut, alhasil setiap penggembala secara rasional akan menambah jumlah ternaknya untuk merumput disana guna memaksimalkan keuntungan. Lihat Garret Hardin, The Tragedy of The Commons, dalam jurnal Science New Series Vol 162, (American Association for the Advancement of Science, 1968) hlm. 1243-1248

12 Elinor Ostrom, Governing the Commons: The Evolution of Institutions for Collective Action, (Cambridge University Press: New York 1990) 
ada aturan penggunaan sumber daya sama sekali yang dapat diterapkan dan tidak ada kepercayaan antar sesama anggota kelompok.

\subsection{Hak Biokultural Dalam Jurisprudensi dan Rezim Hukum Lingkungan Internasional}

Konvensi Keanekaragaman Hayati (UN Convention on Biodiversity/UNCBD) merupakan instrumen hukum internasional pertama yang secara eksplisit mengakui keterkaitan antara kearifan lokal masyarakat adat dan masyarakat lokal dengan konservasi keanekaragaman hayati. Pasal 8(j) dan 10(c) dari konvensi ini mewajibkan 193 negara anggotanya untuk melindungi kearifan lokal masyarakat dengan menjamin integritas budaya, mendorong penggunaan sumber daya hayati tradisional yang berkelanjutan dan menghargai struktur pembuatan kebijakan dalam masyarakat adat dan masyarakat lokal tersebut.

Protokol Nagoya mengenai Akses Terhadap Sumber Daya Genetik dan Pembagian Keuntungan yang Adil dan Seimbang Atas Pemanfaatannya merupakan peraturan pelaksana UNCBD yang memperkuat pengakuan terhadap hak biokultural masyarakat sebagai pengampu sumber daya genetik dan pengetahuan tradisional terkait. Protokol ini tidak hanya mengakui masyarakat adat/lokal sebagai pihak pelestari yang harus dimintai persetujuan di awal ketika hendak mengakses sumber daya genetik, tetapi mereka juga diakui sebagai pengampu yang berhak mendapatkan pembagian keuntungan dari penggunaan sumber daya tersebut.

Spesifik dalam hal konservasi, Durban Accord dan Durban Action Plan yang disepakati pada tahun 2003 dalam IUCN Vth World Congress on Protected Area menjadi panduan bagi konservasi dunia untuk mempertimbangkan nilai budaya dan spritual dalam konservasi, pengakuan terhadap konservasi yang dilakukan masyarakat lokal dan masyarakat adat serta partisipasi mereka dalam pengelolaan kawasan konservasi dilindungi. Durban Accord juga menekankan pada peran kawasan konservasi dalam pembangunan berkelanjutan, jasa ekologis serta peningkatan penghidupan masyarakat sekitar.

Sementara itu, dalam hal jurisprudensi putusan peradilan, The Inter-American Court on Human Rights telah menghasilkan beberapa putusan yang menggunakan dalil hak biokultural dalam pertimbangannya. Pada kasus Community Mayagna (Sumo) Awas Tingni v Nicaragua (2001), pengadilan ini menyatakan kegiatan logging yang disetujui pemerintah telah merusak lingkungan dan mengganggu hak suku Mayagna untuk menjalankan kebudayaan dan kearifan lokalnya. Dalam kasus Yakye 
Axa v Paraguay (2005), pengadilan ini menekankan bahwa sangat penting untuk diperhatikan bahwa tanah sangat berkaitan dengan ekspresi oral dan tradisi, budaya dan bahasa, kesenian dan ritual, pengetahuan traditional dan praktek budaya yang terkait dengan alam, kuliner, hukum adat, pakaian, filosofi dan nilai-nilai sosial. Dalam kasus Comunidad Yanomami (1985), Inter-American Commission on Human Rights menyatakan bahwa pembangunan jalan tol oleh pemerintah Brazil telah melanggar hak masyarakat adat dan mengancam keberlangsungan hidup mereka. Komisi ini menegaskan bahwa efek penggusuran masyarakat suku Yanomami dari tanah leluhurnya tidak hanya tentang kehilangan tanah tapi juga berdampak nagatif bagi kebudayaan dan tradisi mereka. Dalam kasus Lubicon Lake Band $v$ Canada (1990), The Human Rights Committee juga mengakui pentingnya tanah bagi kebudayaan masyarakat adat. Komite ini menegaskan bahwa dampak lingkungan dari ekstraksi minyak dan gas di tanah adat telah menyebabkan pelanggaran hak masyarakat adat atas kebudayaannya sebagaimana dijamin oleh pasal 27 ICCPR. ${ }^{13}$ Di Indonesia sendiri Mahkamah Konstitusi melalui putusan No. 35/PUU-X/2012 yang menyatakan bahwa hutan adat bukan lagi termasuk dalam hutan negara juga menggarisbawahi ikatan sosial budaya masyarakat adat dengan hutan adatnya.

\section{Hak Biokultural Dalam Kebijakan Konservasi Keanekaragaman Hayati di Indonesia}

Kebijakan konservasi di Indonesia mulai mengalami pergeseran paradigma, dari yang awalnya berprinsip konservasi untuk konservasi itu sendiri menjadi konservasi yang memiliki fungsi sosial-ekonomi bermanfaat bagi masyarakat lokal. Konservasi tidak memisahkan manusia dengan alam sekitarnya. ${ }^{14}$ UU No. 5 Tahun 1990 tentang Konservasi Sumber Daya Alam Hayati dan Ekosistemnya memang sangat sedikit mengatur mengenai pengakuan hak biokultural masyarakat dalam upaya konservasi. Pasal 37 UU No. 5 Tahun 1990 mengatur mengenai peran serta masyarakat namun pasal ini membatasi peran serta masyarakat diarahkan dan digerakan oleh pemerintah, serta tidak jelas pula bagaimana peran serta ini akan dijalankan. Belasan tahun kemudian barulah peraturan pelaksana UU No. 5 Tahun 1990 mulai dengan

13 Chen,C.,Gilmore,M.Biocultural Rights: A New Paradigm for Protecting Natural and Cultural Resources of Indigenous Communities, dalam The International Indigenous Policy Journal, 6(3), hlm. 7-8

14 Santosa A dkk, Konservasi Indonesia Sebuah Potret Pengelolaan dan Kebijakan, (Bogor: Pokja Kebijakan Konservasi,2008), hlm. 45-56 
tegas mengakomodasi partisipasi masyarakat seperti Peraturan Menteri Kehutanan No. P.19 Tahun 2004 Tentang Kolaborasi Pengelolaan Kawasan Suaka Alam dan Kawasan Pelestarian Alam, disusul dengan Peraturan Menteri Kehutanan No. P.56 Tahun 2006 tentang Pedoman Zonasi Taman Nasional yang memberikan ruang bagi peran masyarakat dalam penetapan zona kawasan Taman Nasional. Berbagai program kolaborasi (co-management) pengelolaan taman nasional mulai dilakukan, ${ }^{15}$ bentuk kemitraan lain seperti Kesepakatan Konservasi Masyarakat (KKM) juga diharapkan menjadi mekanisme partisipasi masyarakat dalam konservasi dengan tetap memperhatikan hak biokulturalnya. ${ }^{16}$

Undang-undang lain terkait konservasi sumber daya hayati seperti UU No 32 Tahun 2009 tentang Perlindungan dan Pengelolaan Lingkungan Hidup, ${ }^{17}$ UU No 41 Tahun 1999 tentang Kehutanan, ${ }^{18}$ UU No 31 Tahun 2004 Tentang Perikanan ${ }^{19}$ dan UU No 27 Tahun 2007 tentang Pengelolaan Wilayah Pesisir dan Pulau Pulau Kecil ${ }^{20}$ secara normatif semuanya telah menyinggung peran masyarakat dan kearifan lokal dalam kegiatan konservasi, meskipun belum konkrit mengatur bagaimana pengejawantahan kearifan lokal ini dalam praktek konservasi.

\section{Sebagai contoh pengelolaan kolaboratif di Taman Nasional Kayan Mentarang}

16 Seperti Kesepakatan Pemburu Lebah Madu di Taman Nasional Lore Lindu, Kesepakatan Bersama pemanfaatan hasil hutan non-kayu di kawasan Hutan Lindung Kemukiman Manggamat di Kawasan Ekosistem Leuser.. Lihat Sastrawan Manullang, Kesepakatan Konservasi Masyarakat dalam Pengelolaan Kawasan Konservasi, (Jakarta: The Natural Resource Management/ EPIQ Programs bekerjasama dengan Bappenas dan PKA Kemenhut, 1999), hlm. 5-11

17 UU No. 32 Tahun 2009 memasukan asas kearifan lokal sebagai salah satu asas perlindungan dan pengelolaan lingkungan hidup (pasal 2). Undang-undang ini juga mengamanatkan pemerintah untuk membuat dan mengimplementasikan kebijakan mengenai pengakuan masyarakat adat, hak masyarakat adat serta kearifan lokalnya terkait perlindungan dan pengelolaan lingkungan hidup (pasal 63 ayat (1), (2) dan (3)). Informasi mengenai Kearifan lokal ini pun harus tercantum dalam Sistem Informasi Lingkungan Hidupa (pasal 62).

18 UU No. 41 tahun mengakui adanya hutan adat (pasal 5 ayat (1) dan (2)) dan hak-hak masyarakat adat untuk memungut hasil hutan dan melakukan pengelolaan hutan berdasarkan kearifan lokal mereka (pasal 67 ayat (1)). Pada awalnya undang-undang ini menempatkan hutan adat sebagai hutan negara, namun setelah adanya putusan Mahkamah Konstitusi No 35/PUU-X/2012 hutan adat dinyatakan terpisah dari hutan negara dan berada dalam penguasaan penuh masyarakat adat. Meskipun telah mengakui hak-hak masyarakat adat, undang-undang ini masih dikritis karena syarat pengakuan masyarakat adat yang dianggap memberatkan dan tidak sesuai dengan kondisi beberapa kelompok masyarakat adat di Indonesia.

19 Pasal 6 ayat (2) UU No. 31 tahun 2004 menyatakan bahwa Pengelolaan perikanan untuk kepentingan penangkapan ikan dan pembudidayaan ikan harus mempertimbangkan hukum adat dan/atau kearifan lokal serta memperhatikan peran serta masyarakat.

20 UU No. 27 Tahun 2007 menempatkan kearifan lokal sebagai asas (pasal 3) serta lebih lanjut mengakui, menghormati, dan melindungi hak-hak Masyarakat Adat, Masyarakat Tradisional, dan Kearian Lokal atas Wilayah Pesisir dan Pulau-Pulau Kecil yang telah dimanfaatkan secara turun temurun (pasal 61 ayat (1)). Pengakuan ini dijadikan acuan dalam Pengelolaan Wilayah Pesisir dan Pulau-Pulau Kecil yang berkelanjutan (pasal 61 ayat (2)). 
Kolaborasi dan kemitraan yang sesungguhnya dimana para pihak dianggap setara dan mempunyai hak serta kewajiban masing-masing merupakan salah satu kunci sukses konservasi dengan pendekatan biokultural. ${ }^{21}$ Meskipun sudah banyak digalangkan bentuk-bentuk partisipasi masyarakat dalam konservasi, praktek kebijakan konservasi Indonesia masih memandang negara sebagai aktor utama konservasi. Praktek kebijakan konservasi keanekaragaman hayati seolah memandang hanya di tanah milik negaralah konservasi dapat dijalankan. Hal ini tidak jarang menimbulkan konflik tenurial di wilayah konservasi. Sebagai contoh penetapan kawasan hutan, beberapa pihak memiliki kekhawatiran bahwa putusan MK 35 akan mengancam konservasi karena hutan adat tidak lagi termasuk hutan negara sehingga harus dikeluarkan dari penetapan kawasan hutan. Jika dikeluarkan dari kawasan hutan, maka alih fungsi lahan akan menjadi lebih mudah.

Padahal, tidak satupun pasal di UU No 41 Tahun 1999 mengkorelasikan secara tegas fungsi hutan dengan status penguasaan hutan. Harusnya dimungkinkan meskipun status hutan adalah hutan adat namun tetap berfungsi sebagai kawasan konservasi. Penetapan hutan adat sebagai kawasan hutan atau kawasan konservasi dengan tetap mengakui hak ulayat masyarakat adat akan memberikan perlindungan ganda bagi wilayah tersebut dari pihak-pihak tidak bertanggungjawab yang ingin menjual tanah adat, toh dalam hukum adat pun hutan adat ini adalah milik bersama yang tidak boleh dipindahtangankan kepemilikannya pada pihak lain dan mempertahankan hutan adat sebagai hutan juga sejalan dengan kearifan lokal mereka. Dengan cara ini, konservasi dapat dilakukan dengan tetap menghormati hak-hak biokultural masyarakat.

Melekatkan fungsi konservasi dalam hutan adat bukan merupakan praktek baru. Sebagai contoh di Filipina, sebagian kawasan taman nasional Gunung Kitanglad memiliki status sebagai hutan adat (ancestoral domain) yang diakui oleh negara. Pengakuan hutan adat suku ini disertai dengan pengakuan hak biokultural mereka serta kesepakatan untuk mempertahankan hutan sebagai wilayah konservasi. ${ }^{22}$ Hal ini mungkin dapat dicontoh oleh Indonesia sebagai praktek kolaborasi konservasi dengan masyarakat setempat.

21 Lihat Michael C. Gavin et al. Defining Biocultural Approaches to Conservation, dalam Trends in Ecology \& Evolution Journal. March 2015, vol. 30, no.3

22 Taman Nasional Gunung Kitanglad adalah salah satu ASEAN Heritage Park yang terkenal dengan kesuksesan kolaborasi masyarakat adat dengan pemerintah dalam manajemennya. Hasil wawancara Penulis dengan Manajemen Taman Nasional Gunung Kitanglad dan perwakilan masyarakat adat yang tinggal di sekitar taman nasional yaitu Dato Makapukaw Adolino L. Saway, Bae Inatlawan Adelino Docenos, Dato Manlalarawan Edi Rautraut. 5-6 November 2015 
UU No 5 Tahun 1990 juga belum mengakui secara formal konservasi yang dilakukan masyarakat di luar wilayah konservasi yang ditetapkan undang-undang. Konservasi menurut undang-undang ini hanya terbatas di wilayah Kawasan Pelestarian Alam dan Kawasan Suaka Alam yang berada dibawah kewenangan Kementerian Lingkungan Hidup dan Kehutanan. Sementara konservasi yang dilakukan secara mandiri oleh masyarakat belum begitu dibahas dalam peraturan ini. Konservasi mandiri masyarakat dapat dilihat dari praktek masyarakat adat Ammatoa Kajang di Sulawesi Selatan yang mempertahankan 374 hektar hutan mereka tetap alami. Hutan masyarakat adat Ammatoa Kajang ini termasuk dalam kawasan Indigenous Peoples' and Communities Conserved Territories and Areas (ICCAs), ${ }^{23}$ sebuah initiatif internasional yang mendorong konservasi oleh masyarakat adat dan masyarakat lokal yang mempunyai hak biokultural terhadap teritorinya. ${ }^{24}$ Selain itu, berbagai studi juga menemukan praktek komunitas lokal dalam konservasi ekosistem yang luput dari perhatian, seperti Petani campuran (Melayu, Bali, Jawa, Cina) di sekitar Taman Nasional Gunung Palung dengan kebun durian campurannya, Petani di Sungai Telang dan Batu Kerbau Jambi dengan sistem tata guna lahan desanya serta Masyarakat Dayak di Apo Kayan Kalimantan Timur dengan sistem perladangan daur ulangnya. ${ }^{25}$ Sekali lagi, praktek ini menunjukan bahwa peran konservasi tidak harus terpusat pada negara sebagai aktor utama, wilayah yang dikuasai masyarakat pun bisa mempunyai fungsi konservasi.

Selain pengakuan terhadap tenurial tanah, penghargaan terhadap sistem pengetahuan tradisional juga berperan penting dalam menjamin hak biokultural dalam konservasi keanekaragaman hayati. ${ }^{26}$ Pengetahuan tradisional dan kearifan lokal hendaklah diintegrasikan ke dalam rencana dan kegiatan konservasi. Pengetahuan tradisional yang dikembangkan dan disempurnakan dari generasi ke generasi ini hendaklah dipandang sebagai petunjuk atau temuan awal bagi para ilmuwan untuk dikembangkan secara lebih sistematis dan akademis. Selain menjadi komplementer dari ilmu pengetahuan dan teknologi ilmiah, pengetahuan tradisional dan kearifan lokal ini dapat pula mempengaruhi penerimaan sosial masyarakat terhadap program konservasi. Sebagai contoh, praktek manajemen

23 Wahyu Chandra, Belajar Konservasi Dari Masyarakat Adat Se-Asia. Seperti Apa Itu? Artikel diunduh dari http://www.mongabay.co.id/2015/08/25/belajar-konservasi-darimasyarakat-adat-se-asia-seperti-apa-itu/ pada 1 November 2015

24 http://www.iccaconsortium.org/

25 Santosa A dkk, Konservasi Indonesia Sebuah Potret Pengelolaan dan Kebijakan, (Bogor: Pokja Kebijakan Konservasi,2008), hlm. 49-50

26 Lihat Michael C. Gavin et al. Defining Biocultural Approaches to Conservation, dalam Trends in Ecology \& Evolution Journal. March 2015, vol. 30, no.3 
dari taman nasional Gunung Kitanglad di Filipina memadukan pengetahuan dan kearifan lokal dari tiga masyarakat adat yang tinggal di daerah tersebut. Zona inti dari taman nasional ini juga merupakan tempat sakral bagi kelompok masyarakat adat, sehingga masyarakat setempat pun tidak berani mengusik zona inti dan memang menginginkan zona inti untuk tidak diganggu keberadaannya. Ketika ada kegiatan atau pihak yang hendak memasuki zona inti, proses ritual adat harus dijalankan. Ritual ini pun dihormati oleh petugas taman nasional. ${ }^{27}$

Di Indonesia sendiri sebenarnya banyak kearifan lokal yang dapat dipadukan ke dalam rencana konservasi. Pembatasan akses terhadap wilayah tertentu untuk kepentingan konservasi sudah lama dikenal masyarakat. Seperti praktek lubuak larangan dan hutan larangan di Sumatera, atau praktek sasi di papua dan daerah Indonesia bagian timur lainnya. ${ }^{28}$ Jikalau praktek ini dapat sejalan dengan program konservasi, niscaya dukungan masyarakat akan menjadi kuat. Pun ketika ditemukan bahwa praktek tradisional yang dilakukan masyarakat tidak ramah lingkungan, ${ }^{29}$ solusi yang tepat adalah peningkatan kapasitas mereka untuk beralih pada praktek yang lebih ramah lingkungan, bukan malah menghilangkan hak-hak mereka karena dianggap tidak mampu menjaga lingkungan. Perlu diingat bahwa budaya itu tidak statis, sebagaimana pepatah minang alam takambang jadi guru (alam terbentang jadi guru). Alam itu dinamis, beradaptasi dengan perubahan lingkungan. Begitu pula budaya, mengingat ia sebenarnya adalah hasil interaksi manusia dengan lingkungannya.

27 Hasil wawancara Penulis dengan Manajemen Taman Nasional Gunung Kitanglad dan perwakilan masyarakat adat yang tinggal di sekitar taman nasional yaitu Dato Makapukaw Adolino L. Saway, Bae Inatlawan Adelino Docenos, Dato Manlalarawan Edi Rautraut. 5-6 November 2015

28 Lubuak larangan adalah praktek zonasi di wilayah sumatera dimana bagian tertentu dari sungai tidak boleh diganggu oleh masyarakat, biasanya bagian sungai ini adalah tempat bertelur bagi ikan-ikan. Sementara sasi adalah praktek larangan mengambil sesuatu dari alam dalam jangka waktu tertentu, larangan ini memberikan waktu bagi alam untuk beregenerasi.

29 Contoh praktek tradisional yang tidak sustainable adalah penggunaan bubu warin oleh masyarakat sekitar Taman Nasional Danau Sentarum. Bubu Warin merupakan alat tangkap yang destruktif karena akan menangkap seluruh jenis-jenis ikan kecil. Desa sekitar danau ada yang mulai menetapkan larangan menggunakan bubu warin ini. Lihat Gusti Z. Anshari, Dapatkah Pengelolaan Kolaboratif Menyelamatkan Taman Nasional Danau Sentarum, (Bogor : CIFOR,2006), hlm 11-12 


\section{Simpulan}

Pemisahan antara keanekaragaman budaya dan keanekaragaman hayati membuat kita melupakan realitas bahwa keduanya saling mempengaruhi dan memperkuat satu sama lain. Kita tidak dapat memahami dan melestarikan alam tanpa memahami budaya manusia yang membentuknya. Konservasi keanekaragaman hayati hendaklah tidak memutus hubungan biokultural manusia dengan alamnya. Secara normatif, peraturan konservasi di Indonesia telah memuat pengakuan terhadap kearifan lokal dan hak biokultural masyarakat. Namun pada praktek di lapangan, pengejawantahan peraturan ini masih perlu perbaikan. Keikutsertaan masyarakat lokal dan masyarakat adat dalam pengelolaan kawasan konservasi hendaklah menjadi default setting dari sistem manajemen, bukan hal spesial yang baru dibentuk ketika masyarakat sudah menuntut. Masyarakat hendaklah dipandang sebagai partner setara pemerintah yang mempunyai sumber daya dan pengetahuan dalam melaksanakan konservasi. 


\section{Daftar Pustaka}

\section{Peraturan Hukum}

Indonesia. Undang-Undang No. 5 Tahun 1990 tentang Konservasi Sumber Daya Hati dan ekosistemnya.

Indonesia. Undang-Undang No. 5 Tahun 1994 tentang Pengesahan Konvensi Keanekaragaman Hayati.

Indonesia. Undang-Undang No. 41 Tahun 1999 tentang Kehutanan.

Indonesia. Undang-Undang No. 31 Tahun 2004 tentang Perikanan.

Indonesia. Undang-Undang No. 27 Tahun 2007 tentang Pengelolaan Wilayah pesisir dan Pulau-Pulau Kecil.

Indonesia. Undang-Undang No. 32 Tahun 2009 tentang Perlindungan dan Pengelolaan Lingkungan Hidup.

Indonesia. Undang-Undang No. 11 Tahun 2013 tentang Pengesahan Protokol Nagoya.

Indonesia. Putusan Mahkamah Konstitusi Nomor 35/PUU-X/2012

Indonesia. Peraturan Menteri Kehutanan No. P.19 Tahun 2004 Tentang Kolaborasi Pengelolaan Kawasan Suaka Alam dan Kawasan Pelestarian Alam.

Indonesia. Peraturan Menteri Kehutanan No. P.56 Tahun 2006 tentang Pedoman Zonasi Taman Nasional.

\section{Buku dan Jurnal}

Anonim. Farmers' Rights in the International Treaty on Plant Genetic Resources for Food and Agriculture artikel dapat diunduh di http://www.farmersrights.org/ about/fr_in_itpgrfa.html

Anshari, Gusti Z. 2006. Dapatkah Pengelolaan Kolaboratif Menyelamatkan Taman Nasional Danau Sentarum.Bogor : CIFOR 
Arobaya, Augustina dan Freddy pattiselanno. 2013. Indigenous People and Nature Conservation. Jakarta: Jakarta Post.

Bavikatte, Kabair Sanjay dan Tom Bennet. 2015. “Community Stewardship : The Foundation of Biocultural Rights dalam Journal of Human rights and the Environment (JHRE) Vol 6, issue 1.

Bavikatte, Kabir Sanjay.2014. Stewarding the Earth: Rethinking Property and the Emergence of Biocultural Rights. Delhi: Oxford University Press.

Bavikatte, Sanjay Kabir. 2011. “Environmental Law as Political Ecology : The Roots of Biocultural Rights" . Makalah dipresentasikan dalam Sustaining Commons: Sustaining Our Future, the Thirteenth Biennial Conference of the International Association for the Study of the Commons.

Chandra, Wahyu. 2015. Belajar Konservasi Dari Masyarakat Adat Se-Asia. Seperti Apa Itu?. Artikel diunduh dari http://www.mongabay.co.id/2015/08/25/belajarkonservasi-dari-masyarakat-adat-se-asia-seperti-apa-itu/

Chen,C. Gilmore, M. 2015. “Biocultural rights: A New Paradigm for Protecting Natural and Cultural Resources of Indigenous Communities" dalam The International Indigenous Policy Journal, Vol 6 Issue 3. Artikel dapat diunduh di http:/ /ir.lib.uwo.ca/cgi/viewcontent.cgi?article=1205\&context=iipj

Gavin, Micheal C. Dkk.2015. “Defining Biocultural Approaches to Conservation dalam Trends in Ecology E Evolution Journal Vol 30 No.3

Hardin, Garret Hardin.1968. "The Tragedy of The Commons" dalam jurnal Science New Series Vol 162. American Association for the Advancement of Science.

Jaszi, Peter. 2010 “Traditional Culture: A Step Forward for Protection in Indonesia”, Washington College of Law Research Paper No. 2010-16, American University Washington College of Law.

Maffi, Luisa. 2008. "Biocultural Diversity and Sustainability". Dalam The Sage Handbook of Environment and Society. Sage Publication Ltd.

Maiero, Marina dan Xiomeng Shen. 2004. "Commonalities Between Cultural and Biodiversity. 
Manullang, Sastrawa. 1999. Kesepakatan Konservasi Masyarakat Dalam pengelolaan Kawasan Konservasi. Jakarta: EPIQ Program's Protected Area Management Office.

Nababan,Abdon. 2002. Pengelolaan Sumber daya Alam Berbasis Masyarakat Adat, Tantangan Dan Peluang Kearifan Tradisional : Awal bagi Pengabdian Pada Keberlajutan Kehidupan, makalah disajikan dalam "Pelatihan Pengelolaan Lingkungan Hidup Daerah" Pusat Penelitian Lingkungan Hidup, IPB.

Ostrom,Elinor. 1990. Governing the Commons: The Evolution of Institutions for Collective Action. New York: Cambridge University Press

Pretty, Jules dkk. 2009. "the Intersections pf Biological Diversity and Cultural Diversity : Toward Integration" dalam Conservation and Society Journal.

Pretty, Jules. 2009. “The Intersections of Biological Diversity and Cultural Diversity: Towards Integration". Dalam Conservation and Society. Diunduh dari

Purwanto, Semiarto Aji. 2005. "Taman Nasional, Hak-hak Masyarakat Setempat dan pembangunan regional" dalam Jurnal Antropologi Indonesia Vol 29, No.3

Santosa, Andri dkk. 2008. Konservasi Indonesia, Sebuah Potret Pengelolaan dan Kebijakan. Bogor : Pokja Kebijakan Konservasi.

Supriatna, Jatna. Peran Kearifan Lokal dan Ilmu-Ilmu Kepribumian Dalam Pelestarian alam. Depok: Research Center of Climate Change UI.

UNEP dan UNESCO. 2003. Cultural Diversity and Biodiversity for Sustainable Development. Nairobi: UNEP \&UNESCO.

UNESCO. 2008. Links Between Biological and Cultural Diversity. Paris: Impremerie Watelet-Arbelot.

Utama, I Made S dan Nanniek Kohdrata. 2011. Modul Pembelajaran Konservasi Hayati Dengan Kearifan Lokal. Denpasar : Universitas Udaya dan USAID-Texas A\&M University. 